\title{
AD 659500
}

CONFLICTS BETWEEN LOVE AND FAMILY RELATIONSHIPS IN CHINESE FILMS

John H. Weakland

Mental Research Institute

Palo Alto, California

Processed for ...

DEFENSE DOCUMENTATION CENTER DEFENSE SUPPLY AGENCY

U. S. DEPARTMENT OF COMMERCE / NATIONAL BUREAU OF STANDARDS / INSTITUTE FOR APPLIED TECHNOLOGY

\section{UNCLASSIFIED}

